Images in...

\title{
Superior mesenteric artery dissection
}

\author{
Taro Shimizu, ${ }^{1}$ Yasuharu Tokuda ${ }^{2}$ \\ ${ }^{1}$ Emory University, Atlanta, Georgia, USA \\ ${ }^{2}$ Department of General Internal Medicine, Tsukuba University, Mito, Ibaraki, Japan
}

Correspondence to Dr Taro Shimizu, shimizutaro7@gmail.com

\section{DESCRIPTION}

A 61-year-old man presented with a 2-day history of epigastralgia and back pain without nausea, vomiting, haematemesis or melena. He reported that he had untreated hypertension. On examination, his upper extremity blood pressures were 180/100 (right arm) and 177/98 $\mathrm{mm} \mathrm{Hg}$ (left arm). His abdomen was soft and flat, but showed epigastric tenderness without rebound tenderness or muscle rigidity with normal bowel sound. Abdominal ultrasonography revealed decreased blood flow at the proximal portion of superior mesenteric artery (SMA). Abdominal CT with contrast enhancement revealed dissection of SMA from the proximal portion to the ileal artery bifurcation (figures 1 and 2). There was no intestinal wall thickening or gastric intramural emphysema. His pain resolved with

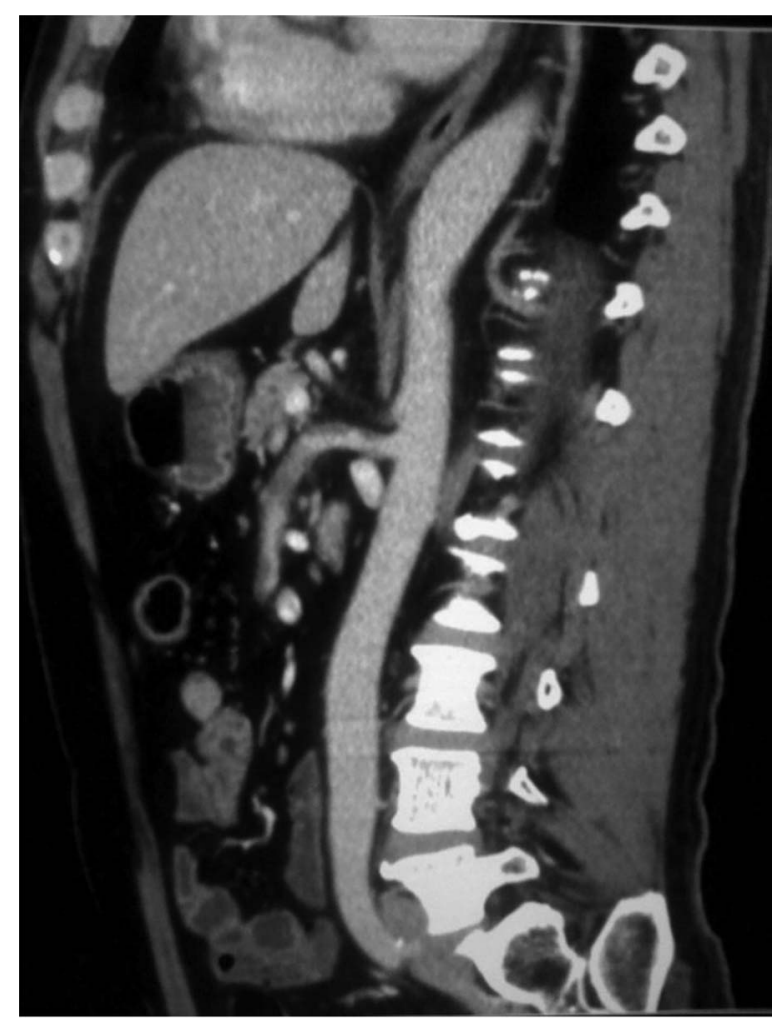

Figure 1 Sagittal section of superior mesenteric artery.

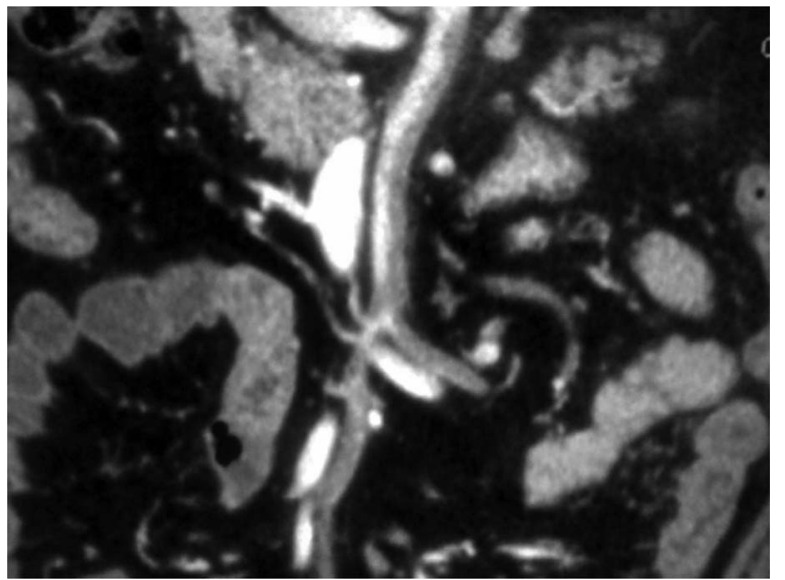

Figure 2 Coronal section of superior mesenteric artery.

conservative management. He was discharged after the symptoms disappeared. He did not have recurrence of the symptom and there was no change in diameter of the false lumen in the follow-up investigation 6 months after the discharge.

Isolated SMA dissection is rare; risk factors include hypertension, trauma, atherosclerosis and connective tissue disorder. ${ }^{1}$ Its diagnosis is usually made by contrastCT scan. As this case, most patients with SMA dissection can be successfully managed with conservative treatment. Surgical treatment or percutaneous intervention can be reserved for patients with severe mesenteric ischaemia and those for whom the initial conservative treatment fails. ${ }^{2}$ After conservative treatment, the majority of patients show clinical improvement. ${ }^{3}$

Competing interests None.

Patient consent Obtained.

\section{REFERENCES}

1. Carter R, O'Keeffe S, Minion DJ, et al. Spontaneous superior mesenteric artery dissection: report of 2 patients and review of management recommendations. Vasc Endovasc Surg 2011;45:295-8.

2. Cho BS, Lee MS, Lee MK, et al. Treatment guidelines for isolated dissection of the superior mesenteric artery based on follow-up CT finding. Eur J Vasc Endovasc Surg 2011;41:780-5.

3. Park YJ, Park KB, Kim DI, et al. Natural history of spontaneous isolated superior mesenteric artery dissection derived from follow-up after conservative treatment. J Vasc Surg 2011;54:1727-33. 


\section{BMJ Case Reports}

Copyright 2012 BMJ Publishing Group. All rights reserved. For permission to reuse any of this content visit http://group.bmj.com/group/rights-licensing/permissions.

BMJ Case Report Fellows may re-use this article for personal use and teaching without any further permission.

Please cite this article as follows (you will need to access the article online to obtain the date of publication).

Shimizu T, Tokuda Y. Superior mesenteric artery dissection. BMJ Case Reports 2012;10.1136/bcr-03-2012-6036, Published XXX

Become a Fellow of BMJ Case Reports today and you can:

- Submit as many cases as you like

- Enjoy fast sympathetic peer review and rapid publication of accepted articles

- Access all the published articles

- Re-use any of the published material for personal use and teaching without further permission

For information on Institutional Fellowships contact consortiasales@bmjgroup.com

Visit casereports.bmj.com for more articles like this and to become a Fellow 